\title{
Trends of Post-fire Forest Recovery in the South Sikhote-Alin Mountains, Russian Far East
}

\author{
T. A. Komarova ${ }^{1)}$ - L. A. Sibirina ${ }^{1)}$ - M. J. Papaik ${ }^{2)}$ - J. H. PARK ${ }^{3)}$ and H. S. Kang ${ }^{3)}$ \\ ${ }^{1)}$ Institute of Biology and Soil Science, Russia Academy of Sciences, Russian Federation, \\ ${ }^{2)}$ Université du Québec à Montréal, Canada, \\ ${ }^{3)}$ National Instrumentation Center for Environmental Management, Seoul National University, Republic of Korea.
}

\begin{abstract}
To understand natural regeneration and stand development after fire in mixed broadleavedconiferous forests of Sikhote-Alin Mountains, ten sample plots of $50 \mathrm{~m} \times 50 \mathrm{~m}$ size were established in 1975 and 1983 at the stands burned by wildfires in 1973 and 1982, respectively. And, the number of naturally regenerated seedlings were monitored in two $50 \mathrm{~m} \times 4 \mathrm{~m}$ subplots in each plot. The most fire-sensitive conifer species is Abies nephrolepis, while Betula costata is the most fire-sensitive broadleaved tree species. The most fire-resistant species were Q. mongolica, T. taquetii and A. mono. The results of 20 and 30 years after the fire showed that pioneer tree species, e.g. Populus, Salix, and Betula, were regenerated immediately at the early stage of stand development and grew where there is a mono canopy layer with high density. On the other hand, the densities of successors, e.g. Pinus koraiensis, Picea jezoensis, Abies nephrolepis, Acer mono and Tilia taquetii, which were present in the study plots before the fire, increased gradually. Naturally regenerated tree species after forest fire by the growth rate were divided into three groups according to their annual height growth. The seral tree species (Betula costata, Betula platyphylla, Padus maackii, Populus tremula and Sarix caprea) belong to the first group and have the highest growth rate (from 40 to $96 \mathrm{~cm}$ per year). The late successional broad-leaved trees (Tilia taquetii, Acer mono and Quercus mongolica) belong to the second group and have intermediate annual height growth (from 3.7 to $13.5 \mathrm{~cm}$ per year). The late
\end{abstract}

\footnotetext{
First author : Tatiana Komarova, Institute of Biology and Soil Sciences, Far East Branch, Russia Academy of Sciences Pr. Stoletia,159, 690022, Russia,

E-mail : mata41@mail.ru

Corresponding author: HoSang Kang, National Instrumentation Center for Environmental Management College of Agriculture and Life Sciences, Seoul National University, Seoul 151-921, Republic of Korea, Tel : +82-2-880-4952, Fax : +82-2-6008-7743, E-mail : silvi1@snu.ac.kr
}

Received : 22 April 2013. Revised : 24 June 2013. Accepted : 24 June 2013. 
successional coniferous species (Picea jezoensis, Pinus koraiensis and Abies nephrolepis) form the third group and have the least annual height growth (from 1.4 to $3.5 \mathrm{~cm}$ per year).

Key Words : forest fire, Russian Far East, natural regeneration, fire-sensitive species, fire-resistant species, forest succession.

\section{INTRODUCTION}

The wildfire is an important source of disturbance in the mixed forests of the South Sikhote-Alin Mountain in the Russian Far East, often resetting the old-growth forest stands to early successional conditions. Forest fire has always been present as a natural component in this forest ecosystem with fire frequency, which has been estimated to be 100-200 years (Mishkov and Starodumov, 1982; Sverlova and Kostyrina, 1985; Sheingauz, 2004). The fires in these forests are characterized by discrete and regular pulses of severe stand-replacing fires, and they essentially create the cyclical pattern of stand development (Kolesnikov, 1956). The stand development proceeds from the immediate post-fire pioneer grass-shrub communities through the intermediate second-growth stands to the native broadleaved forests, which are more susceptible to severe stand-replacing fires than communities of the earlier successional stages. This pattern of fire followed by the relative disturbance-free periods of up to 200 years serves as the essential characteristic of forest dynamics maintaining biodiversity in this region.

The influence of fires on the forest succession has been studied in all forests subjects (Clements, 1928, 1949; Agee, 1993; Pyne, 1995; Shumway et al., 2001; Guyette and Spetich, 2003). This includes a number of studies that have focused on the post-fire development of deciduous broadleaved-Korean pine forests in the Russian Far East (Solodukhin, 1952, 1956; Mishkov and Starodumov 1982; Komarova, 1992). In spite of many studies on forest fires, few of them explicitly has explored the importance of variation in fire severity on the post-fire stand dynamics. The objective of this study is to understand the dynamics of post-fire stands and subsequent stand development after fire across the range of fire severity and habitat conditions.

\section{MATERIALS AND METHODS}

\section{Study area}

1) Abiotic environment

The research was conducted from 1975 to 2004 in the Verkhneussuriskiy Station(VUS), which is located in Pravaya Sokolovka River Basin (tributary of Ussuri River) (Figure 1).

The topographic relief is mainly low to middle-uplands ranging between $500-850 \mathrm{~m}$ above sea level (a.s.l.) with mountain ridges aligned along general direction northeast-southwest. The climate is influenced by the monsoon air circulation and characterized by cold, snowy and sunny winter, and hot and rainy summer. Mean annual precipitation is $700 \mathrm{~mm}$ with more $80 \%$ falling between June and September. The higher range of temperature covers 37 to $39^{\circ} \mathrm{C}$ in July-August, and the lower range covers -45 to 

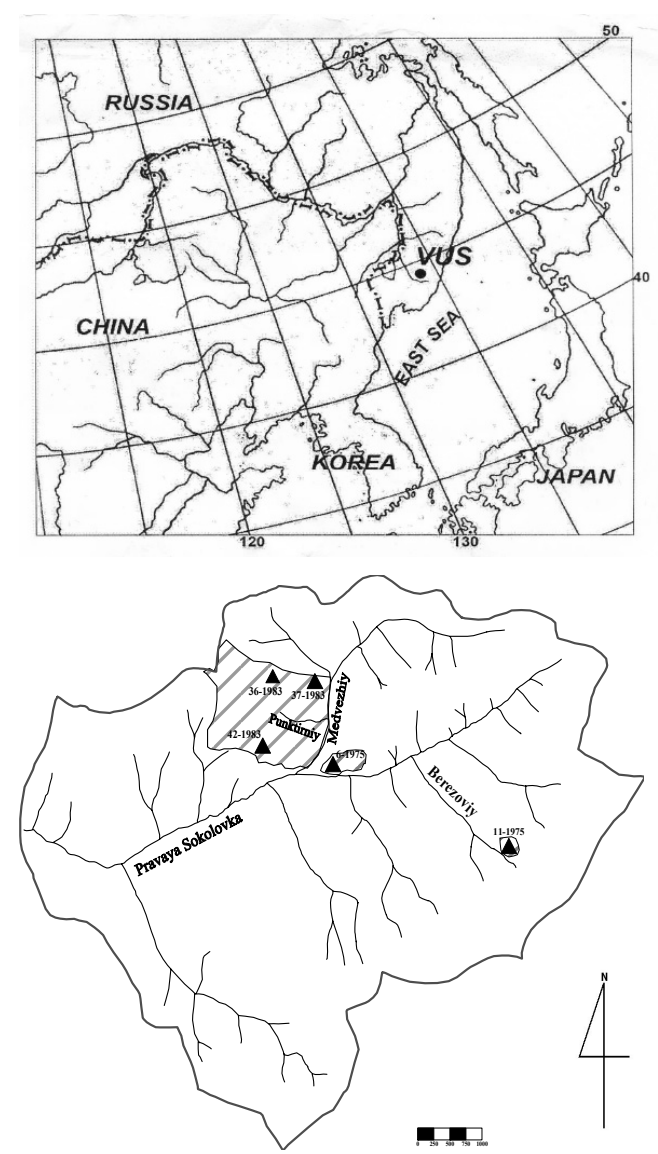

Figure 1. Location map of the study area and sites.

$-48^{\circ} \mathrm{C}$ in January, with an overall mean at $0^{\circ} \mathrm{C}$. Approximately $98 \%$ of the region is broadleavedconiferous forest. Korean pine (Pinus koraiensis) is the most common tree species at lower elevations sometimes forming single species mono-layer stands, but the broadleaved-coniferous forests is characterized by multi-species and multi-layered stands of Korean pine mixed with several broadleaved species, including Quercus mongolicae, Tilia taquetii, Acer mono, Acer tegmentosum, and Ulmus laciniata etc. At elevations higher than $800 \mathrm{~m}$ a.s.l. the broadleavedKorean pine forests are replaced by dark coniferous fir-spruce forests, primarily consisting of Picea jezoensis and Abies nephrolepis. These taiga forests are characterized by a comparatively simple structure and homogeneous composition. The transition zone between the two forest types is a mix of dark coniferous-Korean pine forests formed by $P$. koraiensis, $P$. jezoensis and $A$. nephrolepis.

The major soil type is brown forest soil with well-developed fertile humus horizon. In forest areas in the South of Primorskiy Krai this soil reaches $800-900 \mathrm{~m}$ a.s.l. The inconsiderable process of podzolization has rather similar characteristic of Korean pine-dark coniferous forests.

\section{2) Post-fire sites}

The fire ignition is highly influenced by human activity, weather and forest conditions. The frequency and intensity of fires depend on the type of the fuel sources, which is directly correlated with forest vegetation and site conditions. Sheshukov (1967) classified the fuel sources into 17 types in the Russian Far East and reported that the fuel sources directly depend on the stand density while fire danger is correlated to slope direction. The most dangerous areas are dry insolated slopes with the least being shadowy slopes and valleys.

The xeric and meso-xeric oak-Korean pine forests, which grow on the steep southern slopes, have the greatest fire hazard. The fire season begins just after snow melt in spring and continues through to late autumn. The spring fires are mostly short-term ground fires. However, autumn fires are characterized by long-term ground fires that sometimes transfer to become crown fires. An autumn fire occurred on September and October in 1982 that covered about 15 ha in forests of different types. On the 
top of the steep slope at the elevation of $650-670 \mathrm{~m}$, a steady ground fire turned into intensive crown fire in meso-xeric Rhododendron mucronulatum-oak-Korean pine forest, where the sample plot (s.p.) 42-1984 was established. Before the fire, the forest consisted primarily of $P$. koraiensis and $Q$. mongolica with some $T$. taquetii, Betula platyphylla, P. jezoensis and A. nephrolepis. The crown fire caused considerable disturbance to tree crowns combusting almost $100 \%$ of pine needles, oak leaves and their smaller branches. Tree trunks were burnt up to $16-18 \mathrm{~m}$ high and only some individuals of $Q$. mongolica were survived. As the result of this

Table 1. Stand characteristics and fire situation of permanent sample plots (s.p.).

\begin{tabular}{|c|c|c|c|c|c|c|c|}
\hline $\begin{array}{l}\text { \# Sample } \\
\text { plot ID/ } \\
\text { \# Section }\end{array}$ & Location & $\begin{array}{l}\text { Year } \\
\text { of fire }\end{array}$ & $\begin{array}{c}\text { Slope } \\
\text { aspect }\end{array}$ & $\begin{array}{l}\text { Gradient } \\
\text { (degree) }\end{array}$ & $\begin{array}{l}\text { Elevation } \\
\text { (m a.s.1.) }\end{array}$ & Forest type & $\begin{array}{c}\text { Degree of disturbance } \\
\text { by fire }\end{array}$ \\
\hline 6-1975/sec.1 & \multirow{7}{*}{$\begin{array}{l}44^{\circ} 02^{\prime} 04^{\prime \prime} \mathrm{N} \\
134^{\circ} 11^{\prime} 06^{\prime \prime} \mathrm{E}\end{array}$} & \multirow{7}{*}{1973} & SW & $20-25$ & $550-570$ & $\begin{array}{l}\text { Xeromesophytic Schisandra } \\
\text { chinensis-Corylus } \\
\text { mandshurica } \text { oak-Korean } \\
\text { pine stand }\end{array}$ & $\begin{array}{l}\text { strongly destroyed by } \\
\text { steady ground fire }\end{array}$ \\
\hline 6-1975/sec.2 & & & NW & $20-25$ & $560-580$ & $\begin{array}{l}\text { Mesophytic broadleaved-Korean } \\
\text { pine liana-mixed shrubby stand }\end{array}$ & $\begin{array}{l}\text { strongly destroyed by } \\
\text { steady ground fire }\end{array}$ \\
\hline 6-1975/sec.3 & & & SW & $20-25$ & $560-570$ & $\begin{array}{c}\text { Xeromesophytic Schisandra } \\
\text { chinensis-Corylus mandshurica } \\
\text { oak-Korean pine stand }\end{array}$ & $\begin{array}{l}\text { fractionally destroyed } \\
\text { by slight ground fire }\end{array}$ \\
\hline 6-1975/sec.4 & & & SW & $20-25$ & $550-570$ & $\begin{array}{c}\text { Xeromesophytic Schisandra } \\
\text { chinensis-Corylus } \\
\text { mandshurica } \text { oak-Korean pine }\end{array}$ & $\begin{array}{l}\text { undisturbed control } \\
\text { stand }\end{array}$ \\
\hline 6-1975/sec.5 & & & $\mathrm{S}, \mathrm{SW}$ & $30-35$ & $600-610$ & $\begin{array}{c}\text { Xeromesophytic Schisandra } \\
\text { chinensis-Corylus } \\
\text { mandshurica } \text { oak-Korean pine }\end{array}$ & $\begin{array}{l}\text { strongly destroyed by } \\
\text { steady ground fire }\end{array}$ \\
\hline 6-1975/sec.6 & & & $\mathrm{S}, \mathrm{SW}$ & $30-35$ & $590-600$ & $\begin{array}{c}\text { Xeromesophytic Schisandra } \\
\text { chinensis-Corylus mandshurica } \\
\text { oak-Korean pine stand }\end{array}$ & $\begin{array}{l}\text { fractionally destroyed } \\
\text { by slight ground fire }\end{array}$ \\
\hline 6-1975/sec.7 & & & $\mathrm{S}, \mathrm{SW}$ & $30-35$ & $590-610$ & $\begin{array}{c}\text { Xeromesophytic Schisandra } \\
\text { chinensis-Corylus mandshurica } \\
\text { oak-Korean pine }\end{array}$ & $\begin{array}{l}\text { undisturbed control } \\
\text { stand }\end{array}$ \\
\hline $36-1983$ & $\begin{array}{l}44^{\circ} 03^{\prime} 05^{\prime \prime} \mathrm{N} \\
134^{\circ} 10^{\prime} 51^{\prime \prime} \mathrm{E}\end{array}$ & 1982 & $S$ & $20-25$ & $660-680$ & $\begin{array}{c}\text { Xeromesophytic Schisandra } \\
\text { chinensis-Corylus mandshurica } \\
\text { oak-Korean pine stand }\end{array}$ & $\begin{array}{l}\text { strongly destroyed by } \\
\text { steady ground fire }\end{array}$ \\
\hline $37-1983$ & $\begin{array}{lll}44^{\circ} & 02^{\prime} & 48^{\prime \prime} \mathrm{N} \\
134^{\circ} 11^{\prime} & 12^{\prime \prime} \mathrm{E}\end{array} \mid$ & 1982 & $\mathrm{NE}$ & 10 & $550-575$ & $\begin{array}{c}\text { Hygromesoptytic } \\
\text { broadleaved-dark-coniferous- } \\
\text { Korean pine grass-sedge-fern } \\
\text { stand }\end{array}$ & $\begin{array}{l}\text { strongly destroyed by } \\
\text { steady ground fire }\end{array}$ \\
\hline $42-1984$ & $\begin{array}{l}44^{\circ} 03^{\prime} 05^{\prime \prime} \mathrm{N} \\
134^{\circ} 11^{\prime} 08^{\prime \prime} \mathrm{E}\end{array}$ & & $S$ & 36 & $580-600$ & $\begin{array}{c}\text { Mesoxerophytic Rhododendron } \\
\text { mucronulatum oak-Korean pine } \\
\text { stand }\end{array}$ & $\begin{array}{c}\text { strongly destroyed by } \\
\text { crown fire }\end{array}$ \\
\hline
\end{tabular}


crown fire, forest litter, herbaceous layer, seedling and saplings were almost completely destroyed. These stands were disturbed by an intensive forest fire about 200 years ago. The characteristic of this site before the crown fire is given in the Table 1.

Xero-mesic oak-Korean pine stands with mixed shrubs on steep and medium slopes are also highly prone to fire. The deep and soft litter layer and thin growing herbaceous cover promote quick fire expansion. We established plot 36-1983 in a stand that suffered an autumn fire in 1982 that spread throughout the xero-mesic Schisandra chinensis-Corylus mandshurica-oak-Korean pine forest located at the top of the steep slope. The stable ground fire completely burned out the deep litter layer, seedlings, saplings and most of the herbaceous cover.

Most fires in the mesic broadleaved-Korean pine forest occur in spring and autumn; in summer the dense forest floor vegetation usually prevents the spreading of fire. We established plot 6-1975 in a stand where an intense summer fire occurred in 1973 on the extended slope of the elongated "nose edge" in the watershed between two rivers. Burn stand covered 2 ha and consisted of two different forest types that were completely destroyed by the fire (Table 1).

Mortality varied in the xero-mesic oak-Korean pine stand located on the south-west and southern slopes. We established seven sections in this plot to capture the variation in the effects of fire. Sections 1, 3 and 4 are mid-slope with slope between 20-25 degree and an elevation of $550-570 \mathrm{~m}$. Sections 5, 6 and 7 are located on the upper slope with 30-35 degree slope and elevation of 590-610m. Sections 4 and 7 are in the late stage of succession and are considered to be the undisturbed control stands, since the last major fire occurred about 200 years ago.

The mesic broadleaved-Korean pine-lianamixed shrubby stand (plot 6-1975 section 2) was severely burned with completely disturbed ground layer and intensively damaged tree layer. After the intensive ground fire, the few survivors were all broadleaved trees (e.g., Q. mongolica and T. taquetii), while all coniferous species were damaged by fire and died. Leaf litter, herbaceous cover, seedlings and saplings were mostly destroyed by fire. There were only some little spots of herbaceous cover left with sedge, fern and herbs. Regeneration primarily came from seed sources in neighboring stands located at higher elevations along the slope.

The higher elevation hygro-mesic broadleaveddark coniferous-Korean pine forests growing on the gentle slopes and flood plain terrace are characterized by a comparatively low fire hazard (Starodumov, 1966) and by a mosaic of burned litter and herbaceous cover, which results from the uneven distribution of fuel sources in the plots with an abundance of dry pine needles and hardwood leaves. In these stands the litter layer usually burns down to the mineral soil exposing tree roots, to which all coniferous trees are sensitive. In 1982 an autumn ground fire swept through the hygro-mesic broadleaved-dark coniferousKorean pine grass-sedge-fern stands growing on the shallow slope of the Medvedzhiy river elevated terrace at an elevation of $550-575 \mathrm{~m}$, where s.p. 37-1983 was established. The soil was periodically humid and alluvial with a humus horizon of $6-8 \mathrm{~cm}$. These stands were harvested using selective cutting mostly of large-sized $P$. koraiensis in 1968-1969. Stand cover was 0.8-0.9 with three layers. In the upper layer (crown cover:0.5, average height :23-25m, average diameter : 
30-40cm), $P$. jezoensis dominated with an admixture of $P$. koraiensis, $T$. taquetii and $B$. costata; in the middle layer (crown cover : 0.3-0.4, average height between $16-18 \mathrm{~m}$ ) was formed by A. nephrolepis and A. tegmentosum. In the lower layer (crown cover: 0.3, height : 12-14m) was dominated by A. nephrolepis, $P$. jezoensis and Acer ukurunduense.

\section{Methods}

We established ten sample plots of 0.25 ha $(50 \mathrm{~m} \times 50 \mathrm{~m})$ in different stands disturbed by forest fires in 1982 and 1973, respectively. All individual trees greater than $2 \mathrm{~cm}$ in $\mathrm{DBH}$ were numbered and mapped. Seedlings were divided into $10-50 \mathrm{~cm}$ size classes and counted in two $50 \mathrm{~m}$ $\times 4 \mathrm{~m}$ subplots in each plot. Trees were classified into three fire effect categories : 1) undamaged, 2) damaged, and 3) dead. For trees classified as damaged, the fire scar height on the stem and the degree of damage to the root system were determined using the procedure developed by Starodumov and Tsibukov (1969) and Sheshukov et al. (1978). The fire scars height on the stems were divided into 5 classes by the size : 0.1-0.5; $0.6-1.0 ; 1.1-2.5 ; 2.6-5.0$; and more than $5.0 \mathrm{~m}$. Depending on the damage degree of a cambium in the basis of trunks, 3 groups have been allocated : 1) weak damaged by the violation of not more than $25 \%$ of the trunk circumference; 2) medium damaged :26-50\%; and 3) strongly damaged : more than $50 \%$. Dynamics of tree mortality has been assessed by the annual revisions on the total percentage of drying trees from original number of each species at the first 10 years after the fire, and then at intervals of 2-5 years.

Scientific names of all the species are referenced from the "Vascular Plants of Soviet Far East” (Volumes. 1-8 1985-1996).

\section{RESULTS AND DISCUSSION}

\section{Impact of fire on standing trees}

The early stage of succession after fire depends in large part on the composition of the survivors of the pre-fire timber stand. Not all of the trees die because of the fire. Some trees get damaged or even undamaged trees die soon after the fire due to strong winds, fungal infection and insect damages that occur soon after a fire.

One year after fire in the xero-mesic oakKorean pine stand (s.p. 36-1983) about $50 \%$ of

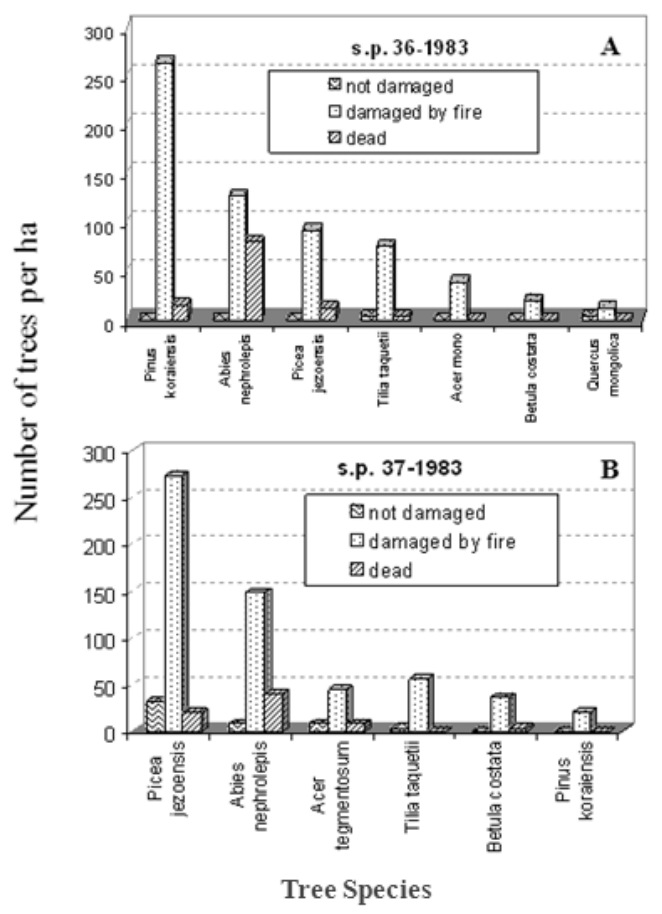

Figure 2. The effect of fire on woody species in the burned stands in the xero-mesic oak-Korean pine forest (A) and hygro-mesic broadleaveddark coniferous-Korean pine forest (B) 
trees had root damage, the stem and roots were damaged in $20 \%$ of trees, $15 \%$ of trees had stem damage, and only two species (Q. mongolica and T. taquetii) were survived (1 each) that were undamaged by the fire (Figure 2).

In broadleaved-dark coniferous-Korean pine stands (s.p. 37-1983), 7\% of trees were undamaged, $62 \%$ had damaged root systems, about $8 \%$ of trees had fire scars on the stem, and almost $10 \%$ of trees had fire damage to both stems and roots. The year following the fire approximately $15 \%$ of the trees of oak-Korean pine stands and $13 \%$ in broadleaved-dark coniferous-Korean pine forests had died. These primarily consisted of $A$. nephrolepis and $P$. jezoensis. Stem scars reached to $5-6 \mathrm{~m}$ on $A$. nephrolepis and $P$. jezoensis in both plots, while $P$. koraiensis were scarred only below $1 \mathrm{~m}$. Because they have finer branches and thin bark most young trees (less than $12 \mathrm{~cm} \mathrm{DBH}$ ) of both broad-leaved and coniferous species have suffered from fire. The drying of large trees occurred most frequently as a result of the thermal damage of cambium at the base of the stem and root system.

Post-fire mortality characteristics among woody species in the burned oak-Korean pine stand (s.p. 36-1983) and broadleaved-dark coniferous-Korean pine stand (s.p. 37-1983) for 11 years after steady ground fire of 1982, and for 30 years after a low intensity ground fire of 1973 in the oak-Korean pine stand (s.p. 6-1975, section 3) reflects the number of the surviving trees of separate species to their pre-fire quantity (Figure 3).

Overall survival rate after six years on s.p. 36-1983 and s.p. $37-1983$ was $25.7 \%$ and $14.6 \%$ respectively. The crown density was $0.2-0.3$ in

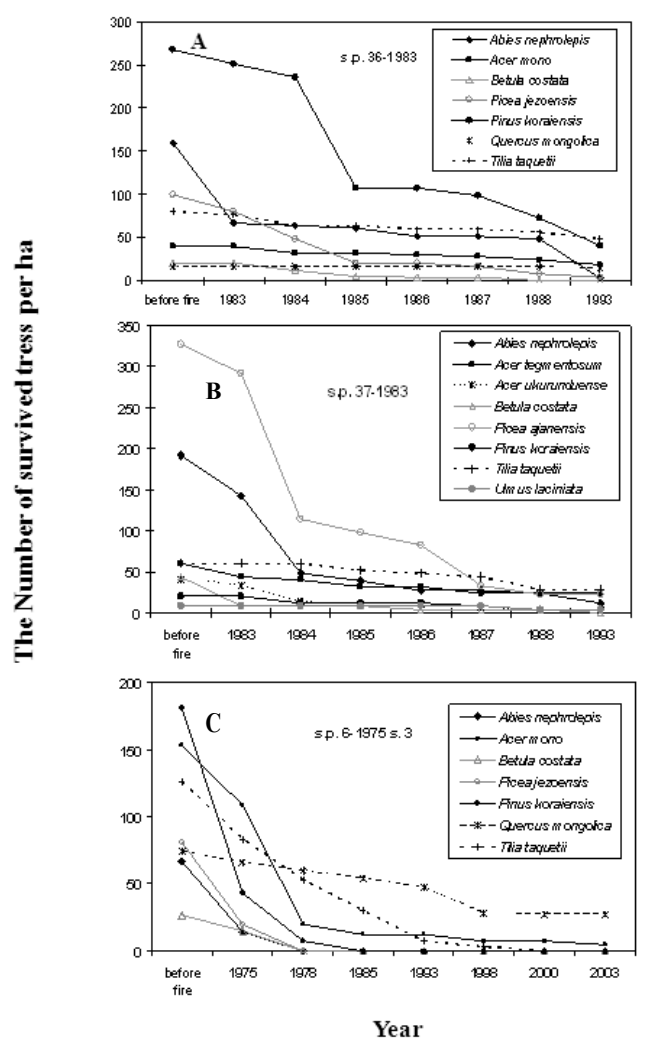

Figure 3. Changes in the survival rate of canopy woody species after fire from 1982 to 1993 in the burned xero-mesic oak-Korean pine forest (A), hygro-mesic broadleaved-dark coniferousKorean pine forest (B) and from 1975 to 2003 in the sparse-burned of xero-mesic oakKorean pine forest (C)

both stands. A few trees of coniferous and broad-leaved species survived only in low intensity burned microtopes in the both stands. In the damaged $P$. koraiensis and $P$. jezoensis bark fell from the larger part of the stem, and the crown consisted of only smaller branches of the $1^{\text {st }}$ and $2^{\text {nd }}$ order. Dead P. koraiensis more than six years after the fire had either lost their apices or were entirely broken stems without crown. On some stems only the bases of the branches of the first order existed, bark became dark and cracked, the 
process of mortality had begun. At 11 years after the fire $19.6 \%$ of all the original trees in s.p. 36-1983 remained viable, while $9.9 \%$ in s.p. 37-1983.

In the severely burned stand where few trees survived (s.p. 6-1975 section 3), crown density decreased from $0.3-0.4$ to 0.2 by the $20^{\text {th }}$ year after fire (Figure-3C). The $P$. koraiensis mixed with $T$. taquetii and $Q$. mongolica, which made up the upper tree layer before fire, was absent. The survival Q. mongolica and T. taquetii had dead tops and were less than $20 \mathrm{~m}$ in height. Few $A$. mono, which had dominated in the lower tree layer before fire, were found. In the $30^{\text {th }}$ year after the fire, section 3 of s.p. 6-1975 consisted mostly of $Q$. mongolica and had crown density of less than $0.1 \mathrm{~m}$. On section 5 of s.p. 6-1975 tree population decline continued longer than other sections and 30 years following fire canopy closure remained lower (0.3) than pre-fire $(0.5)$ and consisted primarily of three species $(Q$. mongolica, T. taquetii and A. mono).

Studies in stands with different fire severity show that tree mortality after intensive ground fires continues for 3-5 years in the stands consisting primarily from $P$. jezoensis and $A$. nephrolepis stands (s.p. 37-1983) and for 6-7 years in broadleaved-Korean pine stands (s.p. 6-1975 sec. 1, 2, and 6, 36-1982). Post-fire mortality continues longer if the initial fire effects were less severe : for 15-20 years after a low intensity ground fire if survived trees have crown density between 0.3-0.4 (s.p. 6-1975, sec. 3) and for 25-30 years after slight ground fires if survived trees have crown density about 0.5 (s.p. 6-1975 sec. 5). The same pattern of post-fire mortality in fir-spruce and broadleaved-Korean pine stands has been observed in other studies (Starodumov and Tsibukov, 1969; Sheshukov et al., 1978). Our study also reveals that the post-fire mortality rate of trees is higher in the first year after crown fire compared to areas exposed to ground fires. For example the crown fire of 1982 in mesoxerophytic oak-Korean pine-rhododendron stands (s.p. 42-1984) caused within one year the death of $99.6 \%$ of $P$. koraiensis, $80 \%$ of $B$. platyphylla and $77 \%$ of Q. mongolica.

On the basis of long-term monitoring of damage rate and destruction of trees growing on the sample plots, the sequence of the tree species along a fire-resistance scale has been elaborated (Komarova et al., 2005). The most fire sensitive conifer species is A. nephrolepis. This is probably due to its thin bark, higher resin content of needles, branches and stem, and shallow root system. P. jezoensis has similar, but less pronounced characteristics and is slightly less susceptible to fire. Species with thicker bark such as $P$. koraiensis are better able to survive at running ground fires. However, a thick dry layer of needles that covers surface roots burns easily, making this species prone to root damage in ground fires as well as other coniferous species. This often results in tree death due to the damage to the cambium layer of the roots and the base of tree. B. costata is the most fire sensitive deciduous tree species, followed in increasing order of fire resistance $A$. ukurunduense, $A$. tegmentosum, B. platyphylla, Padus maackii, Fraxinus mandshurica, Ulmus laciniata, A. mono, T. taquetii, $Q$. mongolica. The most fire resistant species, Q. mongolica, has comparatively thick bark capable of protecting the cambium layer 
from the overheating in all except the most severe fires. Mortality after ground fires is comparatively small. Our results are strikingly similar to the fire resistance scale reported in other studies for these forests (Solodukhin 1954, Starodumov, 1966).

\section{Establishment and growth of the post- fire regeneration of the tree species}

Post-fire stand development is mostly generated within the 4 groups of plants : 1) survivors from the pre-fire stand; 2) those destroyed during fire, but regenerating due to dispersal of diaspores from neighboring stands; 3) those regenerating from sprouts or from dormant seeds preserved in soil; and 4) plants absent in original community but establishing from dispersal of diaspores delivered from outside the burned area. The determination on which species dominates at different times during succession after an intense fire is associated with the lifespan of the species : the shorter lived species dominate at the early stage, while the longer lived ones do at the later stage. Clements (1928) defined three major groups of species : initial, seral and climax species. Initial species (e.g., Aralia elata and Sambucus racemosa) have the shortest life cycle and are found only the first few years after fire. The second group (i.e. the seral species) have longer life duration and occur at the later stages of succession reaching their greatest number of individuals and maximum productivity in the first and middle stages of post-fire recovery. Seral species usually form the new stands of second-growth forests. Climax species have a capacity for a long life and stable self-regeneration in the established second growth forests. The late stages of post-fire succession are generally formed by climax species, which make up the climax community.
The establishment and the growth of a new generation of trees depends on fire intensity and degree of damage on plant cover and litter. Burned sites usually have small-scale heterogeneity of microsites with various degrees of burning out of vegetation, litter and soil (with weak, moderate, strong and very strong disturbance to vegetation and litter), which matches with the four types of post-fire microtopes : 1) with a comparatively well preserved plant cover and litter layer or disturbed less than 50\%; 2) with partially preserved plant cover and litter layer or disturbed more than $50 \%$; 3) with plant cover and litter layer destroyed, but with an undisturbed humus horizon; and 4) with plant cover and litter layer destroyed and a highly damaged humus horizon.

Spatial variation within post-fire communities has a significant influence on tree regeneration and the establishment of herbs and shrubs. Deciduous tree species dominated the extremely high and high intensively burned microtopes of s.p. 37-1983. The two-year growth was fastest for Populus tremula, Populus koreana, Salix caprea, Salix taraikensis, which reached the height of $80-100 \mathrm{~cm}$, whereas the two-year-old B. costata did not exceed the height of $20-30 \mathrm{~cm}$. Orthotropic shrubs; S. racemosa, regenerated dense thickets here did not concede on height to fast-growing young plants of aspens and willows in the first 5 years after fire. Even-age plants of birches, getting behind in growth from them, were severely suppressed their dense crown at this time and their 5-years saplings did not exceed $1.0 \mathrm{~m}$ of height.

In the microsites with moderate and weak fire intensity, various herbaceous species, which regenerated vegetatively, formed dense herbaceous layers dominated by ferns (e.g., Leptorumohra 

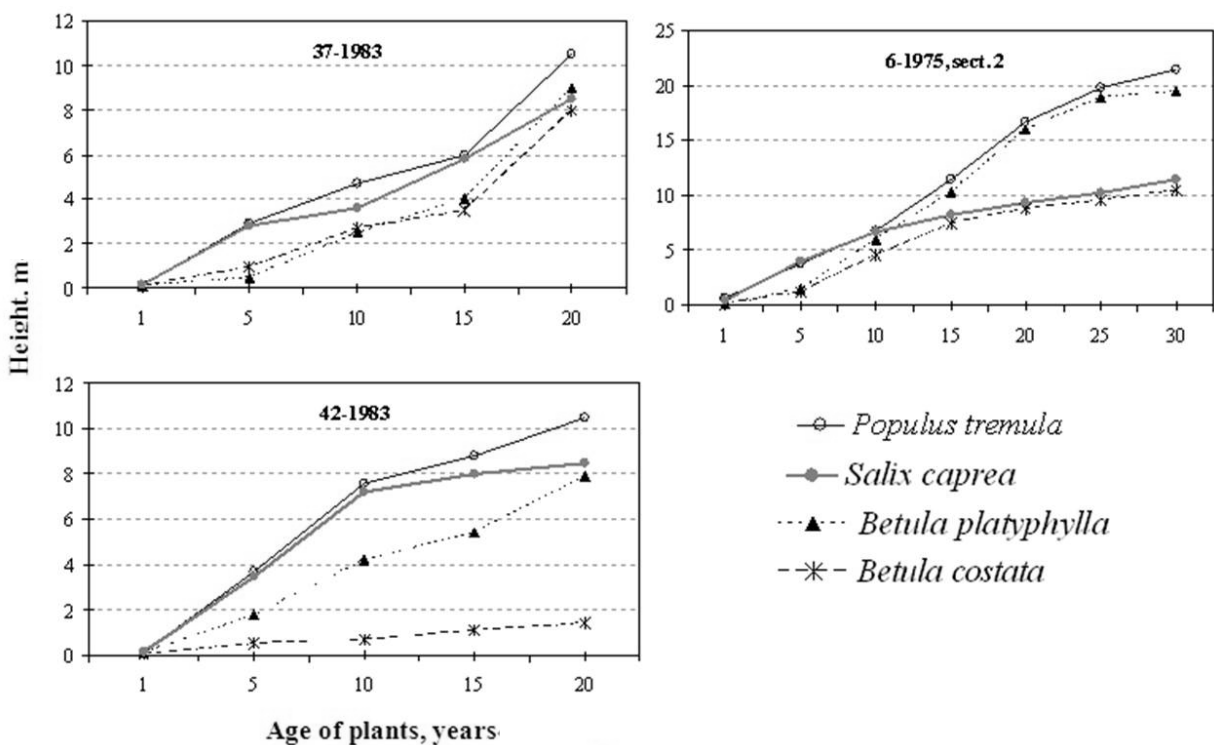

- - - Betula costata

Figure 4. The effect of environments on the height-age relations of some seral species after forest fire.

amurensis, Diplasium sibiricum ) and sedges (e.g., Carex xyphium and Carex Campylorhina). Few individuals of seral species grew where the main roots of coniferous trees burned. In these less severely damaged microtopes the average height of $P$. tremula, P. koreana, and S. caprea was $40-60 \mathrm{~cm}$ and $B$. costata was $5-10 \mathrm{~cm}$. In the following years growth of seral species was very high in the microtopes with high disturbance and the heights of $P$. tremula, $P$. koreana, S. caprea, S. taraikensis reached at total of $4.5-5.0 \mathrm{~m}$ by the $7^{\text {th }}$ year after fire.

The rate of tree growth depends much on environmental conditions. Seral species are more plastic to different environments than climax species, however they also changed in response to environments. The height-age relations were revealed for young plants of some seral species growing on three permanent sample plots representing a wide variety of environmental conditions (Figure 4).
The height-age curves are differ for welldeveloped and suppressed saplings. In order to avoid considerable variations in the shape of the height-growth curves, we estimated only the well-developed young trees. $P$. tremula has lower sensibility to different environments, and its growth is faster than other seral species. $B$. costata is the most sensitive species to environment, and the rate of its growth considerably changes in different sites. The plants of this kind species usually prefer humid habitats and avoid very dry places. In 20 years growing after fire in meso-xeric oak-Korean pine forest (s.p. 42-1984) $B$. costata was not exceeded more than $2 \mathrm{~m}$ in height and most part of these trees were died out.

The growth rate is one of the most important characters of seral and climax species. Based on the tables of the annual height increment coming out of our investigation on different burned sites, it becomes possible to make comparative calculations of mean annual height increment of 
young trees of different seral and climax species (Figure 5).

These woody species can be subdivided into three groups according to their annual height growth. All seral species $(B$. costata, $B$. platyphylla, P. maackii, P. tremula and S. caprea) belong to the first group and have the highest growth rate (from 40 to $96 \mathrm{~cm}$ per year). The climax broad-leaved trees (T. taquetii, A. mono and $Q$. mongolica) belong to the second group and have intermediate annual height growth (from 3.7 to $13.5 \mathrm{~cm}$ per year). The climax coniferous species ( $P$. jezoensis, $P$. koraiensis and $A$. nephrolepis) form the third group and have the least annual height growth (from 1.4 to $3.5 \mathrm{~cm}$ per year).

As crown closure gets more dense, the competition for space, light, moisture, nutrients and minerals increases between young trees. The post-fire regeneration of even-aged individuals of

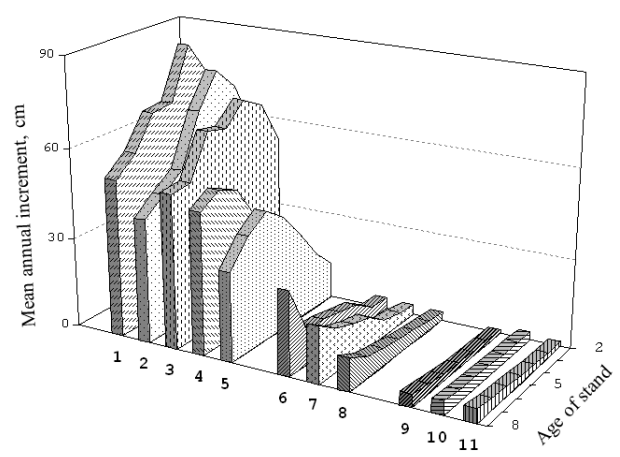

Figure 5. Mean annual height increment of natural regenerated seedlings at different stand ages along post-fire succession in the xero-mesic oak-Korean pine stand.

1 - Populus tremula, 2 - Padus maackii, 3 Salix caprea, 4 - Betula platyphylla, 5 Betula costata, 6-Acer mono, 7 -Tilia taquetii, 8 - Quercus mongolicae, 9 - Picea jezoensis, 10 - Pinus koraiensis, 11 - Abies nephrolepis seral species develops a hierarchy of size with a few well-developed big saplings and large clump of suppressed individuals. The weak trees suppressed by stronger ones have diminished in the process of self-thinning. Natural thinning is the most clearly seen for the first 10 years after fire among seral species. We investigated the dynamics of post-fire regeneration for woody species during 22 years in the broadleaved-dark coniferous-Korean pine stand (Figure 6).

In the first year after fire there were 41.9 thousand seedlings per hectare of 18 woody species, dominated by $P$. tremula (45.4\%) and $S$. caprea $(24.5 \%)$. The germination of birch and coniferous seeds is facilitated by the high ash

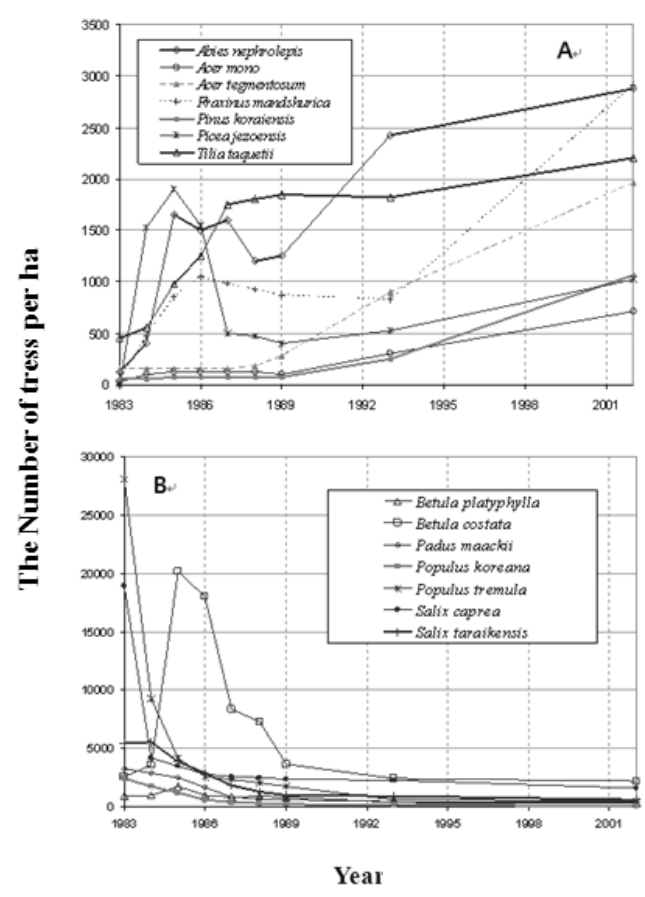

Figure 6. Changes in the quantity of naturally regenerated tree stems less than $2 \mathrm{~cm}$ diameter after fire (A-seral, B-climax species) for 22 years in the broadleaved-dark coniferous-Korean pine forest (s.p. 37-1983). 
content in burned soil. The total number of birch, fir and spruce seedlings increased considerably on the 2-year burn site to 253.8 thousands woody seedlings per hectare, and consisted primarily of B. costata and B. platyphylla $(93.2 \%)$, and $P$. jezoensis and $A$. nephrolepis $(4.3 \%)$. By the $22^{\text {nd }}$ year after fire, only $1.7 \%$ of young $P$. tremula, $6.3 \%$ of S. taraikensis, $6.9 \%$ of S. caprea and $11.3 \%$ of $P$. maackii survived compared to the number of plants in the first year. By the $30^{\text {th }}$ year after fire in the broadleaved-Korean pine stands (s.p.6-1975, sect. 2), only $12.2 \%, 2.9 \%, 2.6 \%$ and $2.6 \%$ of the original seedlings of $P$. tremula, $S$. taraikensis, B. costata and $S$. caprea, respectively, survived.

By 22 years after fire in the broadleaved-dark coniferous-Korean pine stand, seral species formed a simple tree layer due to intensive natural thinning. As a result, the number of young seedlings of climax species began to increase. In s.p. 37-1983 the number of T. taquetii increased by 5.2 times, $P$. koraiensis by $21.9, A$. nephrolepis by 24.5 and $A$. mono by 29.2 compared to the number of naturally regenerated young trees in the first year. In s.p. 6-1975 section 2, the development of young climax species was considerably inhibited by dense layer of herbaceous plants and shrubs. Only after a dense seral species layer subsequently formed that inhibited growth of light sensitive herbaceous plants and shrubs, climax species can be regenerated with less competition in the ground layer. In the $30^{\text {th }}$ year after fire $T$. taquetii increased by $64.7 \%$; P. jezoensis by $66.8 \% ; A$. nephrolepis by $70.4 \%$; P. koraiensis by $78.4 \%$; and $A$. mono by $89.7 \%$ compared to the $2^{\text {nd }}$ year after fire.

\section{CONCLUSION}

As a result of long-term monitoring on the stand dynamics, in broadleaved-Korean pine forests and in broadleaved-dark coniferousKorean pine forest in the South Sikhote-Alin, Primorsky Krai, Russian Far East tree population decrease that had already existed before fire was continued for several years after fire. Furthermore, it was also convinced that the development of new generation of trees depends on the fire intensity, characteristics of tree species, number of survived trees, the initial post-fire abundance of herbaceous plants and shrubs, and the general forest-growing conditions as well. Tree mortality continued for 4-7 years after high intensity fires, while did for 20-30 years after slight fires if crown density of survived trees is $0.4-0.5$. When crown density is more than 0.5 , subsequent forest species composition was not changed by fire. The most fire-sensitive species was $A$. nephrolepsis among conifers and $B$. costata among deciduous species. The most fire-resistant species were $Q$. mongolica, T. taquetii and A. mono. The high growth rate of several species after intensive fires provided good conditions for the development of their first generation. The young generations of climax species have more comfortable conditions to grow at the burned stands where survived trees have crown density $0.4-0.5$.

\section{LITERATURE CITED}

Agee, J. K. 1993. Fire ecology of Pacific Northwest forests. Island Press : Washington D.C.

Clements F. E. 1928. Plant succession and indicators. Wilson : New York.

Clements F. E. 1949. The dynamics of vegetation. 
New York.

Sheingauz A. A. 2004. Forest fire management in high biodiversity value forests of the Amur-Sikhote-Alin ecoregion : Scientifictechnical basis of the project. Khabarovsk, Printing-house "ZhASO-Amur".

Guyette, R. P. and Spetich, M. A. 2003. Fire history of oak-pine forests in the Lower Boston Mountains, Arkansas, USA. For. Ecol. Manage. $180: 463-474$.

Kolesnikov B. P. 1956. Korean pine forests of the Far East. AS USSR : M.L. (in Russian)

Komarova, T. A. 1992. Post-fire succession in the forests of South Sikhote-Alin Mountains, Vladivostok : FEB RAS. (In Russian).

Komarova, T. A. · Sibirina, L. A. - Lee, D. K. and Kang, H. S. 2005. Decomposition of trees after fires in Korean pine forest of the South Sikhote-Alin Mountains. In. : International symposium on ecological conservation and sustainable development of forest resources in Northeast Asia. Yanji, China. pp. 76-77 Mishkov, F. F. and Starodumov, A. M. 1982. Post-fire regenerative changes in Korean pine forests. In : Forest regeneration in mountain forests of the Far East. Khabarovsk. p. 27-34. (In Russian).

Pyne, S. J. 1995. World fire : The culture of fire on earth.

Sheshukov, M. A. 1967. Classification of forest fires on size of the burned out area. Forest regeneration.1, 53-57. (In Russian).
Sheshukov, M. A. · Soloviev, K. P. and Naikrug, I. B. 1978. Influence of various factors on damageability of standing timbers and tree species by fire. In : Usage and reproduction of woody resources of Far East. Khabarovsk, pp. 145-150. (In Russian).

Shumway, D. L. · Abrams, M. L. and Ruffner, C. M. 2001. A 400-year history of fire and oak recruitment in an old-growth oak forest in western Maryland, USA. Can. J. For. Res. 31, 1437-1443.

Soloduchin, E. D. 1952. Forest regeneration in some types of forest within Primorski territory. Communication of FEB SO USSR AS. 5, 43-53. (In Russian).

Soloduchin, E. D. 1954. Natural forest regeneration on clearing and burned stand in fir-spruce forest of the Far East. Forest regeneration.11, 40-42. (In Russian).

Starodumov, A. M. 1966. Character of forest fires on the Far East. Forest industry. pp. 58 (In Russian).

Starodumov, A. M., Tsibukov, B. N. 1969. Effect of forest fire on the decomposition of trees in larch forests of Khabarovski territory. Forest regeneration, 10, 60-63. (In Russian).

Sverlova L. I. · Kostyrina, T. V. 1985. Droughts and forest fires on the Far East. Khabarovsk. pp. 118.

Vascular plants of the Soviet Far East. Science. 1985-1996. Vol.1-8. (In Russian). 